\title{
A comparative study of the effects of two carbamide peroxide bleaching agents on the structure of enamel
}

\author{
Estudo comparativo do efeito de dois agentes clareadores à base de peróxido de carbamida sobre a estrutura \\ do esmalte
}

\author{
Roberto Paulo de ARAÚJO' \\ Danilo Barral de ARAÚJO' \\ Márcio Cajazeira AGUIAR²
}

\section{ABSTRACT}

\section{Objective}

Considering that different sources of carbamide peroxide bleaching agent may cause greater or lesser damage to the enamel and may have reduced effectiveness in dental whitening, the aim of this study was to compare the effects on the structure of enamel of two bleaching agents, drugstore-compounded and commercial carbamide peroxide bleaching agents.

\section{Methods}

The specimens in the first group (drugstore-compounded carbamide peroxide) and second group (commercial carbamide peroxide) were treated with to $16 \%$ carbamide peroxide for $4 \mathrm{~h}$ per day for 20 days. The third group served as a control and was kept in artificial saliva during the test period. After the treatments, all specimens were examined via scanning electron microscopy.

\section{Results}

Changes in the enamel morphology were similar in both experimental groups, but these changes were greater than those observed in the control group. The changes were mild and included only pores.

\section{Conclusion}

There were no differences regarding damage to the enamel between drugstore-compounded and commercial carbamide peroxide bleaching agents.

Indexing terms: Dental enamel. Microscopy, electron, scanning. Tooth bleaching.

\section{RESUMO}

\section{Objetivo}

Comparar por microscopia eletrônica de varredura, os efeitos sobre a superfície do esmalte de um agente clareador à base de peróxido de carbamida comercial e outro preparado em farmácia de manipulação.

\section{Métodos}

Os espécimes do primeiro grupo (confeccionado em farmácias de manipulação) e do segundo grupo (peróxido de carbamida comercial) foram tratados com peróxido de carbamida a $16 \%$ por 4 horas durante 20 dias. O terceiro grupo (controle) foi preservado em saliva artificial durante todo o experimento. Após os tratamentos, todas as amostras foram examinadas por microscopia eletrônica de transmissão.

\section{Resultados}

As alterações foram sutis e compreenderam apenas poros. As alterações na morfologia do esmalte nos grupos experimentais foram similares, mas foram maiores do que aquelas observadas no grupo controle.

\section{Conclusão}

Não foram observadas diferenças na superfície do esmalte dentário entre os agentes clareadores à base de peróxido de carbamida comerciais e aqueles adquiridos em farmácias de manipulação.

Termos de indexação: Esmalte dentário. Microscopia eletrônica de varredura. Clareamento dental.

\footnotetext{
${ }^{1}$ Universidade Federal da Bahia, Instituto de Ciências da Saúde, Departamento de Biofunção, Salvador, BA, Brasil.

${ }^{2}$ Universidade Federal da Bahia, Instituto de Ciências da Saúde, Departamento de Biomorfologia. Av. Reitor Miguel Calmon, Vale do Canela, 40110100, Salvador, BA, Brasil. Correspondência para/ Correspondence to: MC AGUIAR. E-mail: <mcaguiar@ufba.br>
} 


\section{INTRODUCTION}

The color of the tooth is an important issue for dentists and patients who want to improve the appearance of their teeth1. As a result, many studies have been developed with the aim of improving techniques or creating products to whiten teeth without risk to the health of patients.2,3,4,5 The most commonly used products for bleaching teeth are hydrogen peroxide and carbamide peroxide ${ }^{6-7}$.

Carbamide peroxide has been suggested as a safe option for bleaching vital teeth. Most of the available systems employ carbamide peroxide at concentrations ranging from 10 to $35 \%{ }^{8-9}$. There is much controversy regarding the effects of different concentrations of bleaching agents on the enamel structure, 10-11. A study evaluating the effects of various concentrations of carbamide peroxide on the enamel revealed that bleaching agents with lower concentrations of this agent (10 and 16\%) caused fewer changes to the enamel surface ${ }^{12}$.

The bleaching of vital teeth with carbamide peroxide can be accomplished by means of bleaching agents applied in the dentist's office or dental bleaching gels that are used at home under the supervision of a dentist. Such products are generally manufactured by leading companies with worldwide recognition. However, it is also possible to purchase of these bleaching agents from compounding pharmacies that can offer the same product at a lower cost. It is possible that different sources of such a product may result in more or less damage to the enamel and may have reduced effectiveness in tooth whitening. A study analyzing the concentration of carbamide peroxide in bleaching agents prepared by compounding pharmacies noted that the products tested did not have the expected $16 \%$ concentration of carbamide peroxide ${ }^{13}$.

The present study was carried out to compare the effect on the enamel surface of a $16 \%$ carbamide peroxide gel that was industrially produced with that of an agent that was made in a compounding pharmacy. We hypothesized that the origin of a product may interfere with its ability to change the enamel surface, resulting in changes in the structure of the enamel.

\section{METHODS}

\section{Specimen preparation}

Thirty upper and lower human premolar teeth donated by the Teeth Bank of the Metropolitan Union of
Education and Culture (UNIME) were used in this study. Removal of residual soft tissues and teeth cleaning was performed with the aid of Greyce 7 curettes, Robinson brushes, pumice stone and deionized water used with a disk coupled to a low speed motor. The separation of the crowns from the root portion and the buccal surfaces from the lingual or palatine surfaces was completed with the use of a Precision-Cutter ELSAW (ElQuip ${ }^{\circledR}$, São Carlos, SP). The bases of one-half-inch PVC cylinders were sealed with red wax (Epoxiglass ${ }^{\circledR}$, Diadema - SP, Brazil). Inside each cylinder, the dental surface was placed in the center of the sealing wax and allowed to settle so that the wax directly contacted the selected face of the specimen, followed by the inclusion of the other faces in orthophthalic resin.

The 30 specimens were prepared and randomly divided into 3 groups: Experimental Group I consisted of 10 specimens treated with a 16\% carbamide peroxide gel prepared in a compounding pharmacy (Formula ${ }^{\circledR}$, Salvador, BA); Experimental Group II consisted of 10 specimens treated with $16 \%$ carbamide peroxide gel (Whiteness Perfect ${ }^{\circledR}$ FGM, Joinville, SC); and a Control Group that consisted of 10 specimens without any bleaching treatment. The specimens were immersed in remineralizing solution at $37{ }^{\circ} \mathrm{C}$. The experimental protocol, which was executed for 20 days, was based on the following procedures: brushing with white fluoride toothpaste (Oral-B Pró-saúde ${ }^{\circledR}$ with 1.100 ppm fluoride, Procter \& Gamble, Brazil) for 2 minutes with the aid of brushing simulation equipment (ElQuip ${ }^{\circledR}$, São Carlos, SP) adjusted to 540 cycles; Pro-Health ${ }^{\circledR}$ with 1100 ppm fluoride(Procter \& Gamble, Brazil) for 2 minutes with the aid of brushing simulation equipment (EIQuip ${ }^{\circledR}$, São Carlos, SP) adjusted to 540 cycles, simulating the average time of normal brushing. The specimens were dried and the shade was determined by measurement against the VITA Easyshade ${ }^{\circledR}$ Advance spectrophotometer (VITA Zahnfabrik H. Rauter $\mathrm{GmbH} \&$ Co., KG), followed by thermal cycling of the specimens with a Thermal Cycle Simulation machine (ElQuip ${ }^{\circledR}$, São Carlos, SP) that applied 100 thermal cycles of $55^{\circ} \mathrm{C}, 37^{\circ} \mathrm{C}$ and $5^{\circ} \mathrm{C}, 5$ seconds each, to simulate the temperature variations in the oral cavity. Subsequently $16 \%$ carbamide peroxide, either from a compounding pharmacy or the industrially produced gel, was applied; the specimens were maintained for 4 hours at $37^{\circ} \mathrm{C}$ in a plastic collection container. Then, the specimens were rinsed with deionized water, brushed and dried again and a second determination of the enamel shade was performed, followed by re-immersion of the specimens 
in remineralizing solution at $37^{\circ} \mathrm{C}$ for 24 hours. This procedure was repeated during the 20-day trial.

\section{Processing for Scanning Electron Microscopy (SEM)}

The samples were removed from the resin cylinders, and the enamel surfaces were prepared for SEM. The specimens were placed on aluminum stubs with colloidal silver adhesive and sputter-coated with gold in a Bal-Tec SCD 050 apparatus (Bal-Tec SCD 050, Liechtenstein). The enamel surface was examined at 200X, 400X, 1,000X, 2,400X and 5,000X magnifications with an SS-550 Superscanscanning electron microscope $\left(\right.$ Shimadzu ${ }^{\circledR}$ ) operated at $10-15 \mathrm{kV}$. A scan of the entire buccal and palatal surfaces was performed, and the most critical areas were selected for the SEM photomicrographs. The photomicrographs were evaluated by two independent researchers. In the qualitative descriptive histological study, enamel surfaces were examined for the presence of pores, erosions, loss of the aprismatic layer, grooves and craters according to type of bleaching agents.
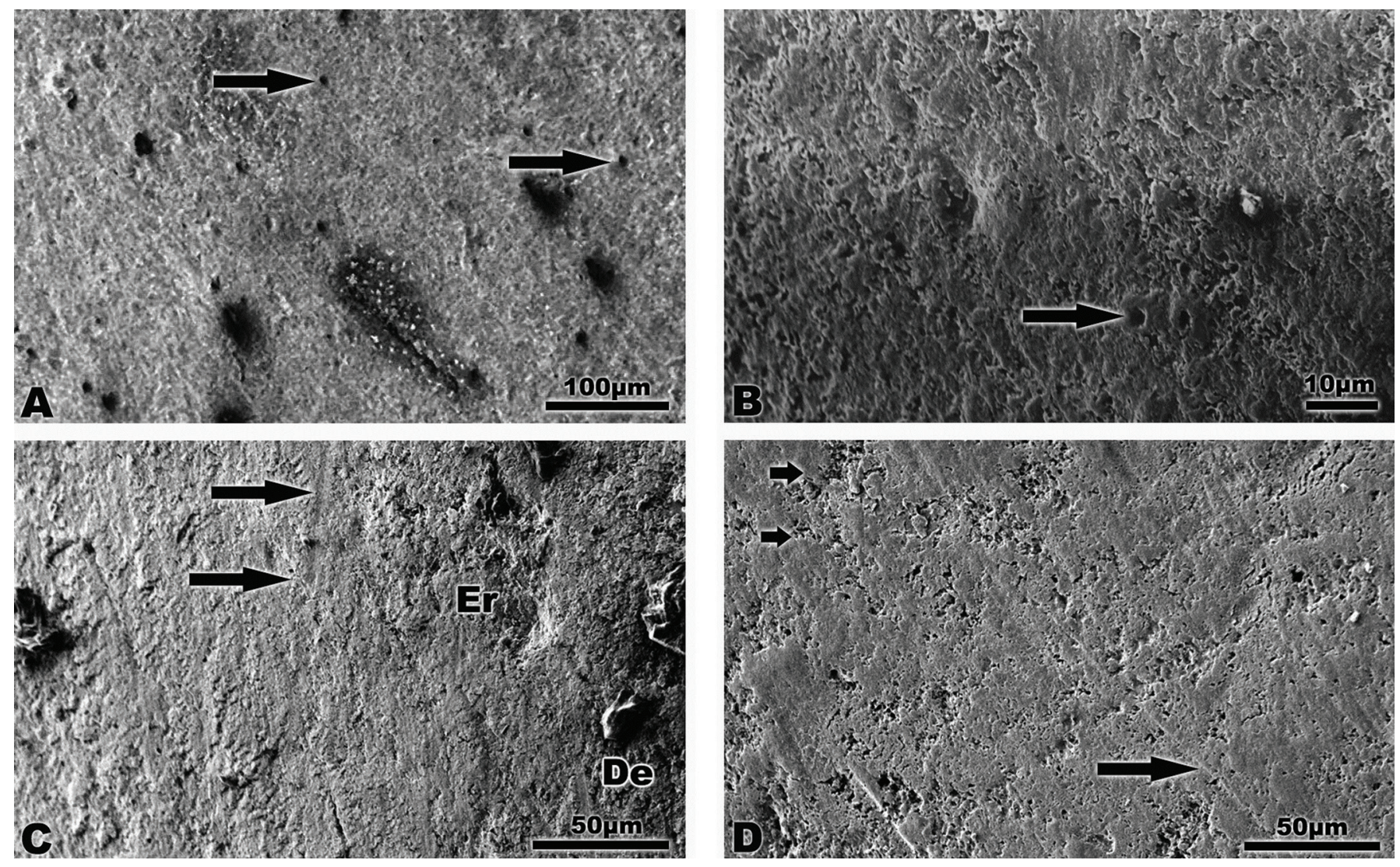

Figure 1. Scanning electron micrographs showing regions of enamel treated with two types of bleaching agents, $16 \%$ carbamide peroxide gel from a pharmacy ( $\mathrm{A}$ and $\mathrm{B}$ ) and a commercial brand of $16 \%$ carbamide peroxide gel (C) and an unbleached enamel surface (D). (A) Note the presence of many pores (arrows) on the enamel surface. (B) A high-magnification view of the enamel revealing many irregularities on the enamel surface. Observe the presence of two pores (arrow). (C) The enamel surface exhibiting many irregularities. Note an erosion (Er), grooves (arrows) and residual debris (De) on the enamel surface. (D) Control group. Some grooves (arrow) on the enamel surface and the partial loss of the aprismatic layer (small arrows) can be noted. 


\section{DISCUSSION}

In the present study, the effects of drugstorecompounded and industrialized bleaching agents on the structure of tooth enamel were compared using two commercially available 16\% carbamide peroxide agents. These agents slightly affected the enamel, producing small structural changes that were not observed in the control group. The most common enamel defects in the specimens from the two different bleaching agents were some pores.

In our study, SEM was used to examine the enamel surface after the tooth bleaching treatments. Many studies have employed this tool to characterize the physical properties of enamel after tooth whitening. SEM has traditionally been considered the gold standard in the studies of enamel surfaces treated with several different agents ${ }^{14-15}$.

Using SEM, this study evaluated the possible effect of carbamide peroxide on the enamel surface using agents with a low concentration of carbamide peroxide (16\%). The side effects of low concentrations of carbamide peroxide on enamel are controversial. Basting et al. ${ }^{16}$ evaluated the microhardness of enamel exposed to different concentrations of carbamide peroxide agents for different bleaching times. Their findings showed a decrease in the microhardness values in the all groups. Oltu \& Gurgan ${ }^{12}$ studied the effect of three bleaching agents containing 10,16 or $35 \%$ carbamide peroxide on the enamel by infrared absorption spectroscopy and X-ray diffraction analysis. These authors observed that 10 or $16 \%$ carbamide peroxide did not change the enamel, whereas 35\% carbamide affected its structure. Considering the above findings, the present study evaluated only the effects of $16 \%$ carbamide peroxide gel, because the use of low concentrations of carbamide peroxide is always recommended over higher concentrations.

In our study, no difference between the 16\% bleaching agents was found, showing that the effects on enamel treated with drugstore-compounded and industrialized carbamide peroxide gels were similar. Different results might have been expected because variations in the chemical composition and conditions of storage among the products could exist. Martin et al. ${ }^{13}$, who analyzed the concentration of $16 \%$ carbamide peroxide bleaching agents prepared by dispensing pharmacies and that of a commercially available product, observed that neither of the bleaching agents presented the expected concentration of $16 \%$. Our findings showed that possible physical or chemical differences between the bleaching agents caused by errors during manufacture did not influence the enamel surface.
However, some alterations on the enamel surface were observed in the experimental samples compared to control, consisting principally of small pores, craters and erosions. Grooves were present on the enamel surface in all the groups and were related to the tooth extraction ${ }^{17}$ or to the polishing treatments. ${ }^{3}$ In the experimental groups, grooves were more clearly prominent, possibly because the enamel surfaces were treated with carbamide peroxide. Indeed, morphologic surface alterations, including the partial removal of the aprismatic layer, an increased depth of enamel grooves, and the exposure of the enamel prisms, were much more pronounced after bleaching. ${ }^{6}$ In the present study, these changes were small and most likely have no clinical impact.

Pores were alterations only observed in the experimental groups. In the enamel, pores arise as a result of spaces created between single crystals in the prism cores and those between prisms. The smaller pores observed in the experimental groups may be associated with the spaces within the prisms themselves ${ }^{18-19}$. These pores could be created by the action of the bleaching agents on the organic or inorganic elements of the enamel matrix ${ }^{20}$.

Some small alterations observed on the enamel surface may be related to an initial process of demineralization. Oltu \& Gurgan ${ }^{12}$, for example, showed changes in the inorganic composition of enamel subjected to carbamide peroxide. It is possible that demineralization could be provoked by the $\mathrm{pH}$ of the carbamide peroxide agents employed in the study ${ }^{16}$. Sa et al. ${ }^{3}$ evaluated the effects of bleaching agents with different $\mathrm{pH}$ values on the human enamel and observed that the agents with low $\mathrm{pH}$ values induced alterations in the enamel surfaces. An in vitro study showed loss of calcium from the enamel exposed to $10 \%$ carbamide peroxide ${ }^{21}$. Indeed, some bleaching agents are acidic and could affect the enamel, dentin and cement. Miranda et al. ${ }^{6}$ evaluated the influence of in-office bleaching agents on human enamel morphology. The $\mathrm{pH}$ values of $35 \%$ carbamide peroxide gel were 6.4 and 3.8. The demineralizing action provoked by the low $\mathrm{pH}$ of the carbamide peroxide could be similar to phosphoric acid. When phosphoric acid is applied to the enamel surface, the acid selectively removes some ends of the enamel prisms. As a consequence, pores and enamel crystallites are exposed, resulting in a retentive surface $^{22}$. The clinical significance of this amount of calcium loss must be examined because human saliva could reverse the demineralization caused by low $\mathrm{pH}$. In the present study, the $\mathrm{pH}$ of the bleaching agents was measured. The $\mathrm{pH}$ of these agents was neutral, indicating that these products did not contribute to enamel demineralization. 
To simulate the environment observed in the oral cavity and the remineralizing potential of saliva, the specimens were kept in a remineralizing solution. The lack of marked changes in the enamel surface in the groups may also have been influenced by the exposure of the specimens to this solution. The remineralizating potential of artificial saliva was observed by Klaric et al. ${ }^{23}$ when they evaluated the influence of five bleaching agents on enamel and dentin surface of 125 human third molars.

\section{CONCLUSION}

In summary, the present findings showed that $16 \%$ carbamide peroxide agents caused small

\section{REFERENCES}

1. Carey CM. Tooth whitening: what we now know. J Evid Based Dent Pract. 2014;14:70-6. doi: 10.1016/j.jebdp.2014.02.006

2. Meireles SS, Fontes ST, Coimbra LAA, Della Bona A, Demarco FF. Effectiveness of different carbamide peroxide concentrations used for tooth bleaching: an in vitro study. J Appl Oral Sci. 2012;20(2):186-91. doi: 10.1590/\$1678-77572012000200011

3. Sa Y, Chen D, Liu Y, Wen W, Xu M, Jiang T, Wang Y. Effects of two in-office bleaching agents with different ph on the structure of human enamel: an in situ and in vitro study. Oper Dent. 2013;38(1):100-10. doi: 10.1590/S1806-83242011000500013

4. de Vasconcelos AA, Cunha AG, Borges BC, Vitoriano JO, AlvesJúnior C, Machado $C T$, et al. Enamel properties after tooth bleaching with hydrogen/carbamide peroxides in association with a CPP-ACP paste. Acta Odontol Scand. 2012;70(4):337-43. doi: 10.3109/00016357.2011.654261

5. Elfallah HM, Bertassoni LE, Charadram N, Rathsam C, Swain MV. Effect of tooth bleaching agents on protein content and mechanical properties of dental enamel. Acta Biomater. 2015;20:120-8. doi: 10.1016/j.actbio.2015.03.035

6. Miranda CB, Pagani C, Benetti AR, Matuda FS. Evaluation of the bleached human enamel by scanning electron microscopy. J Appl Oral Sci. 2005; 13(2):204-11. doi: 10.1590/S167877572005000200021

7. Bonafé $E$, Bacovis $C L$, lensen $S$, Loguercio $A D$, Reis $A$, Kossatz S. Tooth sensitivity and efficacy of in-office bleaching in restored teeth. J Dent. 2013; 41(4):363-9. doi: 10.1016/j. jdent.2013.01.007

8. Cherry DV, Bowers DE, Thomas L, Redmond AF. Acute toxicological effect of ingested tooth whiteners in female rats. J Dental Res. 1993;72(9):1298-303. doi: 10.14219/jada.archive.1996.0414

9. Soares DG, Basso FG, Pontes EC, Garcia Lda F, Hebling J, de Souza Costa CA. Effective tooth-bleaching protocols capable of microstructural changes to the enamel surface. There was no difference in the degree of injury to the enamel when the two groups here in available were compared. However, the findings must be interpreted with caution because this study was performed in vitro and evaluated only bleaching agents that originated from a single compounding pharmacy.

\section{Collaborators}

RP DE ARAÚJO was responsible for the research and writing the article. DB DE ARAÚJO participated in the research. MC AGUIAR participated in analysis and interpretation of results, and writing the article.

reducing $\mathrm{H}(2) \mathrm{O}(2)$ diffusion through enamel and dentine. J Dent 2014;2(3):351-8. doi: 10.1016/j.jdent.2013.09.001

10. do Amaral FL, Sasaki RT, da Silva TC, França FM, Flório FM, Basting RT. The effects of home-use and in-office bleaching treatments on calcium and phosphorus concentrations in tooth enamel: an in vivo study. J Am Dent Assoc. 2012;143(6):580-6. doi: 10.14219/jada.archive.2012.0236

11. Sa Y, Wang Z, Ma X, Lei C, Liang S, Sun L, Jiang T, Wang $Y$. Investigation of three home-applied bleaching agents on enamel structure and mechanicalproperties: an in situ study. J Biomed Opt. 2012;17(3):035002. doi: 10.1117/1.JBO.17.3.035002

12. Oltu U, Gürgan S. Effects of three concentrations of carbamide peroxideonthestructure of enamel. J Oral Rehabil. 2000;27(4):33240. doi: org/10.1590/S1806-83242011000500013

13. Martin JM, Torno V, Vaz MV, Vieira S, Rosa EA, Mazur RF. Specific concentration evaluation of $16 \%$ carbamide peroxide compounded at dispensing pharmacies. Braz Oral Res. 2007;21(4):318-22. doi: 10.1590/S1806-83242007000400007

14. Gjorgievska E, Nicholson JW. Prevention of enamel demineralization after tooth bleaching by bioactive glass incorporated into toothpaste. Aust Dent J. 2011;6(2):193-200. doi: 10.1111/j.1834-7819.2011.01323.x

15. Bodanezi A, de Bittencourt ME, Bodanezi RV, Zottis T, Munhoz EA, Carlini Junior B. Surface modifications on aesthetically restored teeth following home bleaching with $16 \%$ peroxide carbamide. Eur J Dent. 2011;5(2):157-62.

16. Basting RT, Rodrigues Junior AL, Serra MC. The effects of seven carbamide peroxide bleaching agents on enamel microhardness over time. J Am Dent Assoc. 2003;134(10):1335-42. doi: 10.14219/jada.archive.2003.0047

17. Titley K, Torneck CD, Smith D. The effect of concentrated hydrogen peroxide solutions on the surface morphology of human tooth enamel. J Endod.1988;14(2):69-74. doi: 10.1590/ S1806-83242004000400006 
18. Moreno EC, Zahradnik RT. The pore structure of human dental enamel. Arch Oral Biol. 1973;18(8):1063-68. doi: 10.1016/0003-9969(73)90187-8

19. Zahradnik RT, Moreno EC. Progressive stages of subsurface demineralization of human tooth enamel. Arch Oral Biol. 1977;22(10-11):585-91. doi: 10.1016/0003-9969(77)90070X

20. Seghi RR, Denry I. Effects of external bleaching on indentation and abrasion characteristics of human enamel in vitro. J Dent Res. 1992;71(6):1340-44. doi: 10.1177/00220345920710061201

21. McCracken MS, Haywood VB. Demineralization effects of 10 percent carbamide peroxide. J Dent. 1996;24(6):395-98. doi: $10.1590 /$ S1678-77572009000600014
22. Buonocore MG. A simple method of increasing the adhesion of acrylic filling materials to enamel surfaces. J Dent Res. 1955;34(6):849-53. doi: 10.1177/00220345550340060801

23. Klaric E, Rakic M, Sever I, Milat O, Par M, Tarle Z. Enamel and dentin microhardness and chemical composition after experimental light-activated bleaching. Oper Dent. 2015;40(4):E132-41. doi: 10.2341/14-148-L

Received on: 27/8/2015

Final version resubmitted on: 3/3/2016

Approved on: 10/3/2016 